\title{
Rekonstruksi Pengelolaan Komite Sekolah Sebagai Mitra Dalam Peningkatan Mutu Sekolah
}

\author{
Muhamad Faizul Amirudin \\ STAI Bumi Silampari Lubuklinggau \\ amirudin.mfgcf@gmail.com
}

\begin{tabular}{|c|c|}
\hline & \\
\hline $\begin{array}{l}\text { Article History } \\
\text { Received:15 Oktober } 2019 \\
\text { Revised:10November } 2019 \\
\text { Accepted:30 Desember } 2019\end{array}$ & $\begin{array}{l}\text { The lack of the role of the school } \\
\text { committee in education makes it a } \\
\text { school partner to improve its } \\
\text { management. Because it is clear in }\end{array}$ \\
\hline $\begin{array}{l}\text { Keywords : } \\
\text { Pengelolaan, Komite } \\
\text { Sekolah, Mutu Pendidikan }\end{array}$ & $\begin{array}{l}\text { Law number } 20 \text { of } 2003 \text { concerning } \\
\text { National Education System article } \\
56 \text { paragraph } 3 \text { that the school } \\
\text { council approves in improving the } \\
\text { quality of assistance by providing, } \\
\text { directives and support for labor, } \\
\text { facilities and infrastructure, and } \\
\text { supervision of education at the } \\
\text { education level. This paper is a } \\
\text { literature study that uses documents } \\
\text { related to schools and education } \\
\text { suppliers as sources of data and } \\
\text { analyzed using qualitative } \\
\text { descriptive. Reconstruction of the } \\
\text { management of the committee } \\
\text { through improvements to the } \\
\text { planning, organizing, implementing, } \\
\text { and evaluating the work program of } \\
\text { the school committee and education } \\
\text { unit. In addition, training and } \\
\text { guidance for school committees also } \\
\text { requires building good } \\
\text { communication and cooperation } \\
\text { between the school committee, the } \\
\text { government and other parties. That } \\
\text { way it is expected to increase the } \\
\text { strategic role of schools in } \\
\text { improving the quality of education. }\end{array}$ \\
\hline
\end{tabular}




\section{Pendahuluan}

Berlangsungnya pendidikan sebagai salah satu upaya mengembangkan potensi peserta didik dengan berbagai kegiatan perlu dukungan dari berbagai pihak, salah satunya peran masyarakat yang ikutserta bertanggung jawab dalam peningkatan mutu sekolah melalui sebuah organisasi mitra sekolah yaitu komite sekolah. Keberadaan komite sekolah secara legal sudah diatur dalam Permendikbud Nomor 75 tahun 2016 tentang komite sekolah. Namun dalam praktiknya komite sekolah sebagian besar dalam dunia pendidikan mengalami disfungsi, dimana keberadaanya hanya dilibatkan dalam masalah pendanaan saja.

Dari beberapa data hasil penelitian yang penulis kutip terdapat beberapa permasalahan terkait dengan komite sekolah diantaranya penelitian yang dilakukan Hasmiana Hasan (2014:1), yang menyatakan bahwa "komite sekolah kurang berperan dalam menentukan kebijakan sekolah. Peran komite sekolah hanya sebatas menerima laporan dari kepala sekolah. Komite sekolah kurang dilibatkan dalam hal mengambil kebijakan sekolah. Komite sekolah hanya dilibatkan saat pengumpulan dana dari masyarakat. Simpulan dari hasil penelitian adalah fungsi komite sekolah dalam pengembangan dan implementasi program sekolah di SD Negeri 19 Banda Aceh masih kecil. Keterlibatan komite sekolah dalam pengembangan dan Implementasi program sekolah di SD Negeri 19 Banda Aceh hanya 36,37\%. Komite sekolah akan berfungsi penuh dilibatkan oleh pihak sekolah jika ada kaitannya dengan pendanan sekolah yang memerlukan bantuan dari masyarakat".

Selanjutnya hasil penelitian yang dilakukan Ali Mustadi dkk (2016:312), menyatakan bahwa "Implementasi peran program komite sekolah di SD Kabupaten Bantul belum memenuhi standar 100\%. Dimana ditemukan pada Tahap antecedent (input dan perencanaan) pemahaman responden terhadap rancangan program implementasi peran Komite Sekolah belum sepenuhnya sesuai dengan standar dan berkategori cukup dengan persentase $36 \%$. pada Tahap transaction terhadap implementasi program komite sekolah telah terlaksana dengan kategori baik (58\%). Tahap outcomes, yaitu evaluasi terhadap implementasi peran komite sekolah terhadap tahap antecedent dan transaction masuk kategori cukup (47\%)". 
Dari sedikit sampel hasil penelitian di atas menunjukan bahwa peran dan fungsi komite sekolah belum berlangsung secara maksimal dalam membantu meningkatkan mutu pendidikan diberbagai daerah. Tentunya hal ini memerlukan sebuah inovasi dalam pengelolaan agar ke depan keberadaan komite sekolah bisa berfungsi sebagaimana mestinya yang diatur dalam peraturan menteri pendidikan. Untuk itu dalam tulisan ini akan membahas bagaimana merekonstruksi pengelolaan komite sekolah dalam meningkatkan mutu pendidikan.

\section{Metode Penelitian}

Penulisan ini merupakan kajian pustaka dengan menggunakan sumber-sember seperti buku, jurnal, internet, dan dokumen lainnya yang berkaitan dengan komite sekolah dan mutu pendidikan yang selanjutnya dianalisis dengan pendekatan deskriptif kualitatif.

\section{Pembahasan}

\section{Pengertian Komite Sekolah}

Secara historis keberadaan komite sekolah terus mengalami perubahan dari tahun ke tahun. Sebelum tahun 1974 masyarakat di lingkungan masing-masing sekolah telah membentuk Persatuan Orang Tua Murid dan Guru (POMG). Seiring perkembangan pendidikan pada tahun 1974 POMG diganti dengan Badan Pembantu Penyelenggara Pendidikan (BP3). Setelah terjadi reformasi tahun 1998-2002, BP3 berubah nama menjadi Komite Sekolah yang ditetapkan melalui SK Mendiknas Nomor 044/U/2002. Komite Sekolah adalah nama badan yang berkedudukan pada satu satuan pendidikan, baik jalur sekolah maupun luar sekolah, atau beberapa satuan pendidikan yang sama di satu kompleks yang sama (2018:224).

Menurut permendikbud nomor 75 tahun 2016 tentang komite sekolah Pasal 1 ayat 2 dijelaskan bahwa "Komite Sekolah adalah lembaga mandiri yang beranggotakan orangtua/wali peserta didik, komunitas sekolah, serta tokoh masyarakat yang peduli pendidikan"(Permendikbud 2016). Lebih lanjut dalam UU Nomor 20 tahun 2003 tentang Sisdiknas pasal 56 ayat 3 dijelaskan "Komite sekolah/madrasah, sebagai lembaga mandiri, dibentuk dan berperan dalam peningkatan mutu pelayanan dengan memberikan pertimbangan, arahan dan dukungan tenaga, sarana dan prasarana, 
serta pengawasan pendidikan pada tingkat satuan pendidikan"(UU Sisdiknas, 2003).

Menurut Idris (2014:161-62), komite sekolah sebagai lembaga mandiri dibentuk dan berperan dalam peningkatan mutu pelayanan dan memberikan pertimbangan, arahan, dan dukungan tenaga, sarana, dan prasarana serta pengawasan pendidikan pada tingkat satuan pendidikan.

Jadi dapat disimpulkan komite sekolah merupakan lembaga mandiri yang memilik peran dalam memberikan pertimbangan arahan dan dukungan untuk meningkatkan mutu pendidikan. Pertimbangan, arahan, dan dukungan yang diberikan oleh komite sekolah berupa dalam kegiatan merencanakan, mengawasi, dan mengevaluasi pendidikan yang diselenggarakan. Merencanakan berarti turut serta dalam menentukan kebijakan sekolah yang akan dilaksanakan melalui pemberiaan arahan dan pertimbangan yang terkait seperti perencanaan kerja dan anggaran sekolah, perumusan Visi, Misi, dan tujuan sekolah dan lain sebagainya. Pengawasan berarti komite sekolah turut serta memantau pelaksanaan program-program yang telah disepakati agar berjalan sebagaimana mestinya. Evaluasi yang dilaksanakan komite berupa penilaian terhadap pelaksanaan yang telah dilakukan dalam jangka waktu tertentu sebagai bahan pertimbangan perbaikan ke depannya.

\section{Peran, Tugas, dan Tujuan Komite Sekolah}

Keberadaan komite sekolah bukan hanya sebagai pelengkap secara formatif saja, namun lebih dari itu, dimana peran yang dijalankan Komite Sekolah dalam buku panduan dewan pendidikan dan komite sekolah yang dikutip Misbah (2009:4) adalah:

Pemberi pertimbangan (advisory agency) dalam penentuan dan pelaksanaan kebijakan pendidikan di satuan pendidikan.

Pendukung (supporting agency), baik yang berwujud finansial, pemikiran, maupun tenaga dalam penyelenggaraan pendidikan di satuan pendidikan.

Pengontrol (controlling agency) dalam rangka transparansi dan akuntabilitas penyelenggaraan dan pengeluaran pendidikan di satuan pendidikan.

Mediator antara pemerintah (eksekutif) dengan masyarakat di satuan pendidikan. 
Di dalam UU No. 20 tahun 2003 pasal 56 ayat 1 telah dijelaskan bahwa masyarakat berperan dalam peningkatan mutu pelayanan pendidikan yang meliputi perencanaan, pengawasan, dan evaluasi program pendidikan melalui dewan pendidikan dan komite sekolah/madrasah.

Namun dalam praktiknya peran dari komite sekolah mengalami penyempitan akibat dari ketidakpahaman dan kurangnya komunikasi antara pihak sekolah dan komite. Yang kita temui selama ini sebagian besar komite sekolah berperan hanya apabila ada kegiatan yang berkaitan dengan sumbangan dari wali murid.

Tugas komite sekolah pun sebenarnya sudah diatur dalam permendikbud nomor 75 tahun 2016 pada pasal 3 ayat 1 yaitu: memberikan pertimbangan dalam penentuan dan pelaksanaan kebijakan pendidikan terkait:

Kebijakan dan program Sekolah; Rencana Anggaran Pendapatan dan Belanja Sekolah/Rencana Kerja dan Anggaran Sekolah (RAPBS/RKAS);

Kriteria kinerja Sekolah;

Kriteria fasilitas pendidikan di Sekolah; dan

kriteria kerjasama Sekolah dengan pihak lain.

Menggalang dana dan sumber daya pendidikan lainnya dari masyarakat baik perorangan/organisasi/dunia usaha/dunia industry maupun pemangku kepentingan lainnya melalui upaya kreatif dan inovatif; mengawasi pelayanan pendidikan di Sekolah sesuai dengan ketentuan peraturan perundang-undangan; dan menindaklanjuti keluhan, saran, kritik, dan aspirasi dari peserta didik, orangtua/wali, dan masyarakat serta hasil pengamatan Komite Sekolah atas kinerja Sekolah.(Permendikbud, 2016)

Sinergi komite sekolah, masyarakat dan sekolah sangat diperlukan dalam meningkatkan mutu pendidikan, pemahaman dari berbagai pihak terhadap peran dan tugasnya akan mempermudah dari pelaksanaan bebbagai program yang telah disepakati. Untuk itu perlunya membangun komunikasi yang harmonis agar tidak terjadi disfungsi seperti yang terjadi selama ini. Sebagaimana yang dinyataka Hasbullah (2010:95), "adanya sinergi antara komite sekolah dan sekolah menyebabkan lahirnya tanggung jawab bersama antara sekolah dan masyarakat sebagai mitra kerja dalam membangun pendidikan. Dari sini masyarakat akan dapat menyalurkan aspirasi, ide dan partisipasinya dalam memajukan pendidikan di daerahnya". 
Adanya organisasi komite sekolah sebenarnya memiliki tujuan yang sangat bagus dalam meningkatkan mutu layanan pendidikan. Sebagaimana yang diungkapkan Suptapto (2005:34), bahwa komite sekolah bertujuan untuk;

Mewadahi dan menyalurkan aspirasi dan prakarsa masyarakat dalam melahirkan kebijakan operasional dan program pendidikan di satuan pendidikan.

Meningkatkan tanggungjawab dan peran serta masyarakat dalam penyelenggaraan pendidikan di satuan pendidikan.

Menciptakan suasana dan kondisi transparan, akuntabel, dan demokratis dalam penyelenggaraan dan pelayanan pendidikan yang bermutu di satuan pendidikan".

Memang sangat ideal jika kita melihat dari tujuan dibentuknya komite sekolah di atas. Dimana aspirasi masyarakat dapat disalurkan melalui lembaga ini dalam melahirkan kebijakan operasional dan program satuan pendidikan, selain itu agar peran serta masyarakat dalam penyelenggaraan pendidikan meningkat. Namun peran serta masyarakat disini dalam menyalurkan aspirasi sementara ini hanya sebatas bantuan untuk operasional sarana dan prasarana sekolah yang mengadakan pertemuan rapat hanya 1 tahun sekali. Alhasil tujuan yang diidam-idamkan tersebut belum sepenuhnya berhasil.

Disisi lain tujuan tersebut adalah menghendaki agar komite sekolah dapat menciptakan suasana dan kondisi transparan, akuntabel, dan demokratis dalam penyelenggaraan dan pelayanan pendidikan. Transparan berarti adanya keterbukaan dalam berbagai hal, tentu pendanaan dalam satuan pendidikan tersebut termasuk namun tetap dengan kadarnya masing-masing sesuai dengan peraturan dan undang-undang yang berlaku. Akuntabel dimana ketka sudah terjalin transparansi antara sekolah dengan komite maka akan menciptakan suasana yang akuntabel sehingga akan mengetahui factor yang menghambat ataupun yang menunjang melalui laporan pertanggungjawaban secara berkala dari program-program yang telah dilaksanakan. selanjutnya suasana demokratis yaitu pendidikan dari masyarakat dan untuk masyarakat. Sesuai dengan kebijakan pemerintah bahwa masyarakat juga harus ikut andil dalam menentukan arah dan tujuan satuan pendidikan. 


\section{Komite Sekolah dan Mutu Pendidikan}

Berbicara mengenai mutu pendidikan berarti berbicara masalah kualitas pendidikan. Karena pendidikan adalah sebuah system yang terdiri dari berbagai komponen maka untuk memperbaiki mutu pendidikan harus memperbaiki dari keseluruhan komponen tersebut. Sebagaimana dalam UU No. 20 Tahun 2003 tentang Sistem Pendidikan Nasional pasal 54 dijelaskan "Peran serta masyarakat dalam pendidikan meliputi peran serta perseorangan, kelompok, keluarga, organisasi profesi, pengusaha, dan organisasi kemasyarakatan dalam penyelenggaraan dan pengendalian mutu pelayanan pendidikan". Undang-undang tersebut telah jelas memberikan tanggung jawab masyarakat termasuk disini adalah komite sekolah dalam pengendalian mutu pelayanan pendidikan. Secara lebih rinci tugas dari komite sekolah dalam permendikbud nomor 75 tahun 2016 yang telah dijelaskan sebelumnya.

Mutu pendidikan menurut Komariah dan Tiratna (2005:5), artinya menunjuk pada kualitas produk yang di hasilkan lembaga pendidikan atau sekolah. Yaitu dapat di identifikasi dari banyaknya siswa yang memiliki prestasi, baik prestasi akademik maupun yang lain, serta lulusan relevan dengan tujuan.

Dari pengertian itu ada beberapa indikator terhadap mutu pendidikan pertama kuantitas siswa, artinya semakin banyak siswa maka antusias masyarakat untuk masuk pada lembaga pendidikan tersebut juga tinggi, namun tidak hanya berhenti pada kuantitas tetapi dibarengi dengan prestasi siswa yang didapat baik akademik maupun non akademik. Hal ini menunjukkan kalau hanya kuantitas saja belum cukup menunjukkan mutu pendidikan namun kuantitas prestasi siswalah yang menentukannya. Kedua lulusan yang relevan dengan tujuan berarti menunjukkan bahwa sekolah mampu memberikan lulusan yang dicita-citakan bersama, artinya lulusan yang dihasilkan sesuai dengan yang diharapkan masyarakat, industry, institusi itu sendiri dan bangsa ini.

Selanjutnya menurut Salis yang diktip Fadhli (2017:215), menjelaskan bahwa sekolah yang bermutu dan baik memiliki indicator; pertama nilai-nilai moral/ karakter yang tinggi; kedua, hasil ujian yang sangat baik; ketiga, dukungan orang tua, dunia usaha dan masyarakat setempat; keempat, sumber daya berlimpah; kelima, implementasi teknologi terbaru; keenam, kepemimpinan yang kuat dan memiliki tujuan (visi); ketujuh, keperdulian dan perhatian bagi 
siswa; kedelapan, kurikulum yang seimbang dan relevan. Pendapat ini lebih luas lagi dalam menentukan indikator sekolah yang bermutu dibandingkan dengan pendapat sebelumnya. Namun yang perlu digaris bawahi adalah kedua indikator yang disebutkan di atas ada peran masyarakat (komite sekolah) dalam membangun pendidikan yang bermutu.

Lebih lanjut fadhli (2017:219), menyatakan untuk meningkatkan pendidikan yang bermutu dapat lakukan apabila sekolah memiliki dukungan dari pemerintah, kepemimpinan kepala sekolah yang efektif, kinerja guru yang baik, kurikulum yang relevan, lulusan yang berkualitas, budaya dan iklim organisasi yang efektif, dukungan masyarkat dan orang tua siswa.

Berdasarkan penjelasan di atas maka membangun komite sekolah yang bertanggung jawab dalam membangun mutu pendidikan sangat diperlukan. Komite sekolah sebagai mitra sekolah dengan peran dan tugasnya bekerjasama dalam meingkatkan mutu pendidikan untuk menghadapi berbagai tantangan yang diakibatkan dari glbalisasi saat ini. Terutama dalam mempertahankan nilai-nalai luhur bangsa indonesai dan budaya serta penguasaan terhadap Teknologi Informasi dan Komunikasi.

\section{Rekonstruksi Pegelolaan Komite Sekolah}

Kedudukan komite sekolah di satuan pendidikan sangat urgen karena peran dan tugasnya sebagai mitra sekolah meningkatkan mutu layanan pendidikan. Apalagi ditengah era global saat ini pada abad 21 yang memunculkan berbagai tantangan. Untuk itu komite sekolah dituntuk untuk mampu beradaptasi saat terjadi perubahan dan perkembangan IPTEK. Karena mau tidak mau tantangan globalisasi di lingkungan pendidikan harus dihadapi. Untuk itu perlunya merekonstruksi pengelolaan komite sekolah agar tetap mampu memberikan arahan, dukungan dan pertimbang kepada satuan pendidikan.

Pengelolaan Komite Sekolah merupakan "suatu cara untuk mengatur sebuah program, mulai dari perencanaan, pengorganisasian, pelaksanaan, dan evaluasi, dengan memanfaatkan sumber daya yang ada dalam rangka memaksimalkan peran dan fungsi Komite Sekolah agar tujuan dibentuknya Komite Sekolah dapat tercapai secara efektif dan efisien"(Mursidi 2013:24). 


\section{Perencanaan}

Pernecanaan adalah proses dasar dimana manajemen memutuskan tujuan dan cara mencapainya (Sulastri 2014:85). Berkenaan dengan perencanaan program kerja komite sekolah harus menentukan tujuan yang ingin dicapai dengan mengacu pada visi, misi dan tujuan satuan pendidikan. Agar program yang direncanakan sejalan dengan yang dicita-citakan bersama sekolah.

Perencanaan program kerja komite sekolah sesuai dengan peranannya yaitu sebagai pemberi pertimbangan, pendukung, control, dan mediasi harus ikut andil dalam menentukan rencana kerja sekolah, dalam penentuan dan pelaksanaan kebijakan pendidikan di tingkat satuan pendidikan, minimal memberikan masukan, pertimbangan dan rekomendasi kepada satuan pendidikan. Supaya masukan tersebut sesuai dengan kebutuhan satuan pendidikan, diperlukan informasi-informasi yang didasarkan pada kegiatankegiatan, seperti: mengadakan pendataan kondisi sosial ekonomi masyarakat dan sumber daya pendidikan di masyarakat sekitar sekolah; memberikan pertimbangan dalam rangka pengembangan Kurikulum sesuai dengan keadaan sosial dan budaya daerah masingmasing; memberikan masukan dan pertimbangan dalam penyusunan visi, misi, tujuan, kebijakan, program dan kegiatan pendidikan di sekolah, memberikan masukan dan pertimbangan dalam penyusunan RAPBS.

Karena masih belum meratanya SDM yang menjadi komite sekolah maka dalam perencanaan ini diharapkan adanya gotong royong dalam menyusunnya. Karena perlu disadari bahwa tidak semua anggota komite sekolah adalah orang yang faham dengan perencanaan di atas. Maka dari itu perlunya sosialisasi dan pembinaan dari komite sekolah dari tingkat yang lebih tinggi daerah maupun pusat.

\section{Pengorganisasian}

Menurut Priyono (2007:39), hakikat dari organisasi itu adalah manusia dan kerjasama dalam suatu struktur organisasi yang menciptakan pembagian tugas dan jabatan serta meletakkan batasbatas kebebasan seseorang dalam organissi. jadi pengorganisasian komite sekolah dibentuk atas musyawarah dengan melibatkan wali murid, tokoh masyarakat yang peduli pendidikan, dan komunitas 
sekolah dan pakar pendidikan untuk menentukan tugas dan jabatan sebagai komite sekolah sesuai dengan batas-batas kewenangannya.

Menurut penulis dalam penentuan anggota komite sekolah ini perlu pertimbangan yang matang karena tugas dan perannya dalam satuan pendidikan yang tidak mudah. Orang-orang yang terlibat memang benar-benar orang yang mau dan mengerti serta memiliki wawasan yang cukup agar komite sekolah dapat berjalan maksimal. Kalaupun memang belum memiliki kompetensi tersebut perlu adanya pelatihan ataupun pembinaan dari komite sekolah daerah atau pusat dan dewan pendidikan tingkat yang lebih tinggi. Karena sebaik apapun program yang direncanakan tanpa didukung SDM yang menunjang maka tidak akan mampu mencapai tujuan sepenuhnya yang dicita-citakan. Pembentukan organisasi sekolah bukan berdasarkan kedekatan dengan kepala sekolah ataupun orang yang pasif dalam berbagai kebijakan, namun dibutuhkan orang yang kritis terhadap berbagai problem pendidikan yang dihadapi.

\section{Pelaksanaan}

Pelaksanaan merupakan realisasi dari perencanaan yang telah disusun dan disepakati bersama. Pelaksanaan terkait dengan tugas dari komite sekolah yang tercantum dalam permendikbud no 75 tahun 2016. Masalah yang sering terjadi dalam praktiknya dimana komite sekolah hanya sebagai penggalang dana masyarakat dalam rangka pembiayaan penyelenggaraan pendidikan di satuan pendidikan. Untuk itu perlu rekonstruksi dalam sosialisasi tugas komite sekolah agar mereka yang bergabung dalam organisasi komite sekolah faham akan kedudukan dan tugasnya dalam pendidikan.

Sosialisasi tersebut dapat dilakukan oleh komite sekolah atau dewan pendidikan tingkat daerah dan pusat ataupun para pakar pendidikan yang faham dengan hal tersebut. Selain itu dalam pelaksanaan tugasnya komite sekolah perlu membangun komunikasi secara terus menerus dengan pihak sekolah melalui pertemuan rutin yang telah diprogramkan, bisa satu bulan sekali, atau triwulan sekali agar tercipta sinergisitas dalam melaksanakan program bersamasama.

Selama ini komunikasi hanya sebatas dalam pertemuan rapat yang biasa diadakan ketika hendak perpisahan peserta didik. Padahal jika melihat tugas dan peran komite sekolah bukan hanya yang berkaitan dengan pendanaan saja namun lebih dari itu yaitu 
membantu dalam meningkatkan mutu pendidikan yan diselenggarakan. Seperti yang diungkapkan Majir (2018:226), bahwa "hubungan sekolah dengan masyarakat adalah berkomunikasi sampai menimbulkan relasi, yang dapat membina partisipasi masyarakat dan menerima gagasan dan ajakan serta berusaha mensukseskannya. inilah komunikasi yang dibangun bukan selesai rapat selesai pula komunikasi yang dijalin, artinya secara continue bagaimana membina komunikasi yang baik antara sekolah dan komite sekolah sehingga memunculkan kesadaran masing-masing dari masyarakat ataupun sekolah untuk berusaha bersama-sama dalam meningkatkan mutu pendidikan dan mencapai tujuan yang diharapkan.

\section{Evaluasi}

Evaluasi yang harus dilakukan komite sekolah adalah evaluasi tentang seberapa jauh pelaksanaan keempat perannya komite sekolah. Kemudian hasil dari evalusi tersebut dapat dijadikan umpan balik dalam merencanakan kegiatan yang akan datang. Evaluasi merupakan bagian penting dalam pengelolaan komite sekolah. Secara bersamasama dengan sekolah menilai ketercapaian dari tujuan yang direncanakan. Dari hasil evaluasi tersebut akan diketahui faktorfaktor yang menunjang dan yang menghambat dari kegiatan yang dilaksanakan sehinga bisa dijadikan bahan pertimbangan dalam menentukan kebijakan atau keputusan yang mendatang. Evaluasi bukan hanya membuat laporan secara normative tanpa ada pengukuran dan penilaan yang jelas terhadap indicator yang telah ditetapkan. Untuk itu sekali lagi dibutuhkan SDM yang benar-benar memiliki kompetensi dibidang ini. Artinya perlu ditetapkan standar ataupun criteria sebagai anggota komite sekolah. Namun hal tersebut juga menimbulkan permasalah baru kembali pada daerah-daerah terpencil yang memang belum ada SDM yang memadahi. Perlu sebuah kebijakan baru dari pemerintah daerah maupun pusat dengan dinas pendidikan agar mampu memeratakan terhadap SDM komite sekolah melalui berbagai pelatihan dan pembinaan pada kelompok sekolah atau daerah masing-masing.

Di abad ke 21 saat perlunya melakukan inovasi terhadap pengelolaan komite sekolah sebagai upaya menjawab berbagai tantangan yang dimunculkan merupakan sebuah keharusan. Sebenarnya perubahan manajemen sudah dilakukan oleh pemerintah dari pola lama yang bersifat sentralistik menuju pola baru yang 
bersifat desentralistik. Berikut table perubahan pola manajemen dari depdiknas tahun 2001 yang divisualisasikan oleh sudadio (2012:565)sebagai berikut:

Table.1

Perubahan pola manajemen pendidikan menurut (depdiknas 2001: 7)

\begin{tabular}{|l|c|l|}
\hline \multicolumn{1}{|c|}{ Pola Sentralistik } & Menuju & \multicolumn{1}{|c|}{ Pola Desentralistik } \\
\hline Subordinasi & Menuju & Otonomi \\
\hline $\begin{array}{l}\text { Pengambilan keputusan } \\
\text { terpusat }\end{array}$ & Menuju & $\begin{array}{l}\text { Pengambilan keputusan } \\
\text { partisipatif }\end{array}$ \\
\hline Ruang gerak kaku & Menuju & Ruang gerak luwes \\
\hline Pendekatan birokratik & Menuju & Pendekatan professional \\
\hline Sentralistik & Menuju & Desentralistik \\
\hline Diatur & Menuju & Motivasi diri \\
\hline overegulasi & Menuju & deoveregulasi \\
\hline Mengontrol & Menuju & Mempengaruhi \\
\hline Mengarahkan & Menuju & Menfasilitasi \\
\hline Menghindari resiko & Menuju & Mengelola resiko \\
\hline Gunakan uang semua & Menuju & Gunakan uang seefisien mungkin \\
\hline Individual yang cerdas & Menuju & Teamwork yang cerdas \\
\hline Informasi pribadi & Menuju & Informasi terbagi \\
\hline Pendelegasian & Menuju & pemberdayaan \\
\hline Organisasi herarkis & Organisasi datar \\
\hline
\end{tabular}

Dalam konsep perubahan mananjemen di atas memang sudah baik, namun dalam praktik di lapangan belum sepenuhnya dilaksanakan sesuai dengan harapan. Untuk itu dalam rekonstruksi pengelolaan komite sekolah diperlukan kerjasama dari berbagai pihak, sebagaimana menurut mujir (2018:228), bahwa dalam menghadapi globalisasi pendidikan langkah tepat dan cepat perlu diambil untuk menjamin terbentuknya generasi yang kompeten sesuai dengan tuntutan perkembangan, salah satunya adalah semua pihak 
(masyarakat, sekolah dan pemerintah) melakukan kerjasama tanpa batas waktu dan ruang.

Mengingat bahwa globalisasi ditandai salah satunya hilangnya sekat dan batas Negara dalam mengakses informasi dan pengetahuan. Perlunya memperbaiki mindset masyarakat bahwa pendidikan bukan hanya tanggung jawab sekolah dan pemerintah namun juga partisipasi masyarakat dalam berbagai hal juga sangat diperlukan. Apabila mampu menciptakan loyalitas dan integritas dalam pelaksanaan pendidikan mudah-mudahan akan membantu mempercepat mencapai tujuan pendidikan dengan ditunjang beberapa hal diantaranya yaitu; peningkatan kompetensi SDM dalam berbagai disiplin ilmu baik pihak sekolah, masyarakat, dan pemerintah, kesamaan visi, misi, dan tujuan, menciptakan hubungan yang baik antara ketiganya.

\section{Simpulan}

Inovasi pengelolaan komite sekolah sebagai upaya untuk memperbaiki persoalan-persoalan yang ada melalui perbaikan pada perencanaan, pengorganisasian, pelaksanaan, dan evaluasi program kerja komite sekolah dan satuan pendidikan diharapkan mampu meningkatkan peran strategis komite sekolah dalam pendidikan. Perlu adanya upaya peningkatan kompetensi SDM komite sekolah melalui pelatihan dan pembinaan secara sistematis serta menjalin komunikasi yang baik dan berkesinambungan antara sekolah dan komite sekolah agar memiliki kesamaan visi, misi, dan tujuan. Karena untuk menjadikan pendidikan yang bermutu memerlukan dukungan dari berbagai pihak selain dari pemerintah dan sekolah perlu dukungan masyarakat dan orang tua siswa.

Selain itu kerjasama antara sekolah, masyarakat, dan pemerintah serta lintas organisasi lain merupakan salah satu solusi tepat dan cepat dalam menghadapi berbagai tantangan yang muncul di abad 21 saat ini. Melalui kerjasama yang baik akan menciptakan sebuah public relation yang baik pula. 


\section{DAFTAR PUSTAKA}

Fadhli, Muhammad. 2017. "Manajemen Peningkatan Mutu Pendidikan." TADBIR: Jurnal Studi Manajemen Pendidikan 1(2):215-40.

Hasan, Hasmiana. 2014. "Fungsi Komite Sekolah dalam Perkembangan dan Implementasi Program Sekolah di SD Negeri 19 Kota Banda Aceh." Jurnal Pesona Dasar PGSD Universitas Syiah Kuala 2(3):1-12.

Hasbullah. 2010. Otonomi Pendidikan. PT. Raja Grafindo Persada: Jakarta.

Idris, Ridwan. 2014. Manajemen Pendidikan dalam Aplkasinya di Sekolah. 1 ed. Alauddin University Perss: Makasar.

Majir, Abdul. 2018. "Rekonstruksi Hubungan Komite Sekolah dan Sekolah Sebagai Upaya Meningkatkan Mutu Pendidikan." Prodi PGSD STKIP Santu Paulus, Ruteng-Flores 10(2):9.

Misbah, M. 2009. "Peran dan Fungsi Komite Sekolah dalam Meningkatkan Mutu Pendidikan | INSANIA : Jurnal Pemikiran Alternatif Kependidikan.” 14(1):15.

Mursidi, Ali. 2013. "Pengelolaan Komite Sekolah Dalam Meningkatkan Mutu Pendidikan Di SD Islam Al Azhar 29 Semarang." Jurnal Manajemen Pendidikan Universitas PGRI Semarang 2(1).

Mustadi, Ali, Enny Zubaidah, dan Sumardi Sumardi. 2016. "Peran Komite Sekolah Dalam Peningkatan Mutu Pembelajaran Di Sekolah Dasar." Jurnal Cakrawala Pendidikan 35(3).

Permendikbud. 2016. Permendikbud Nomor 75 Tahun 2016 tentang Komite Sekolah.

Priyono. 2007. Pengantar Manajemen. Zifatama Publisher: Surabaya. 
Sudadio. 2012. "Peningkatan Mutu Pendidikan Dasar Dan Menengah Di Provinsi Banten Melalui Manajemen Berbasis Sekolah." Jurnal Penelitian Dan Evaluasi Pendidikan 16(2):553-73.

Sulastri, Lilis. 2014. Manajemen Sebuah Pengatar. Sejarah, Tokoh, Teori dan Praktik. La Good Publishing: Bandung.

Suptapto. 2005. Pengantar Manajemen Sumber Daya Manusia. Rineka Cipta: Jakarta.

Undang-Undang Nomor 20 Tahun 2003 tentang Sistem Pendidikan Nasional.

Tiratna, Aan Komariah dan Cepi. 2005. Visonary Leadershif, Menuju sekolah Efektif. Bumi Aksara: Jakarta. 